\title{
ANALISIS TEORI DAN EKSPERIMENTAL PENGUMPUL SURYA DUA-PASS DENGAN MEDIA BERPORI
}

\author{
Supranto \\ Jurusan Teknik Kimia, Fakultas Teknologi Industri \\ UPN "Veteran" Yogyakarta \\ e-mail: supranto@yahoo.com
}

\begin{abstract}
The double-pass solar collector with porous media in the lower channel provides a higher outlet temperature compared to conventional single-pass collector. Therefore, the thermal efficiency of the solar collector is higher. The solar collector can be used for wide variety of applications such as solar industrial process heat and solar drying of agricultural products. A theoretical model has been developed for the double-pass solar collector. An experimental setup has been designed and constructed. Comparison of the theoretical and the experimental results have been conducted. Such comparisons include the outlets temperatures and thermal efficiencies of the solar collector for various design and operating conditions. Close agreement has been obtained between the theoretical and experimental results.

Keywords: double-pass solar collector, porous media, theoretical, experimental, efficiency.
\end{abstract}

\section{PENDAHULUAN}

Tenaga surya merupakan sumber energi dunia, dari tenaga surya ini akan tercipta sumber-sumber energi baru dan sumber kehidupan. Energi merupakan bagian yang sangat penting dalam setiap bidang kegiatan. Selain itu energi juga merupakan komponen penting dalam pertumbuhan ekonomi, disamping modal, tenaga kerja dan bahan baku. Semakin besar dan maju suatu kegiatan akan semakin besar pula energi yang dikonsumsi. Sehingga biaya penyediaan energi mengambil bagian yang besar pula dalam kegiatan yang dilakukan. Dalam kegiatam industri biaya penyediaan energi atau yang lebih popular dikenal dengan biaya bahan bakar dapat mencapai lebih dari 40\% dari biaya produksi [6]. Industri memenuhi kebutuhan energinya dari tenaga listrik dan bahan bakar fosil. Energi listrik yang terutama digunakan untuk a) penggerak, misalnya untuk menjalankan pompa, kompressor dan alat angkut yang lain; b) pemanas, misalnya untuk membuat udara panas, regenerasi penjerap dan pemanas bahan skala kecil; c) pengkondisian, misalnya penyejuk ruangan dan d) penerangan, baik untuk penerangan ruangan, penerangan area pabrik dan penerangan rumah. Hal ini dilakukan apabila tersedia cukup listrik dari perusahaan listrik negara (PLN). Sedangkan apabila tidak tersedia listrik yang cukup, maka perusahaan terpaksa harus menyediakan listrik sendiri. Bila terjadi hal yang demikian, penggunaan bahan bakar akan semakin banyak, karena kebutuhan bahan bakar disediakan untuk pembangkit tenaga listrik. Tenaga listrik tersebut digunakan sama ada di pabrik maupun di perumahan dan fasilitas lainnya. Pembakaran bahan bakar yang lainnya adalah untuk pembangkit "steam" yang banyak diperlukan dalam industri. 
Steam terutama digunakan untuk pemanas dan juga penggerak. Untuk pemanas biasanya digunakan steam jenuh, sedangkan untuk penggerak digunakan steam lewat panas, sehingga kebutuhan bahan bakar akan semakin banyak lagi. Selain pemakai bahan bakar yang sangat rakus, dilain pihak kegiatan industri dituduh sebagai sumber pencemaran lingkungan yang utama. Pencemaran lingkungan dari kegiatan industri dapat berupa buangan padatan, cair dan gas. Dalam kaitannya pemakaian bakar, pencemaran utama ialah dalam bentuk buangan gas. Pencemaran lingkungan akibat pemakaian bahan bakar fosil dapat berupa padatan (dalam bentuk partikel debu hasil pembakaran tidak sempurna bahan bakar dan gas hasil pembakaran dalam bentuk senyawa karbon, senyawa nitrogen dan senyawa belerang. Semakin banyak pemakaian bahan bakar akan semakin banyak pula bahan pencemar yang dihasilkan, sehingga perlu kiranya dicari sumber energi baru yang ramah. Untuk mendapatkan udara panas dapat disediakan dengan pengumpul surya pemanas udara. Hal ini diharapkan akan mengurangi pencemaran udara dan menghemat pemakaian bahan bakar fosil.

\section{LANDASAN TEORI PENGUMPUL SURYA}

Pengumpul surya pemanas udara atau yang dikenal dengan pengumpul surya, menghasilkan udara panas dengan memanfaatkan energi dari sinar matahari. Sinar matahari menimpa pengumpul surya sebagian dipantulkan kembali ke udara sekitar dan sebagian lagi diserap oleh plat penyerap. Karena menyerap panas maka plat penyerap menjadi panas kemudian panas tersebut dipindahkan kepada udara yang mengalir di dalam pengumpul surya.

Pengumpul surya yang baik ialah pengumpul surya yang mempunyai efisiensi tinggi, ini berarti sebagian besar panas dari sinar surya yang menimpanya dapat dimanfaatkan untuk memanaskan udara yang mengalir di dalamnya. Dengan demikian berarti hanya sebagian kecil saja panas yang hilang ke sekeliling. Panas hilang ke sekeliling karena dipantulkan kembali oleh penutup dan plat penyerap dan sebagian lagi hilang ke sekeliling melalui bagian dasar dan bagian sisi dari pengumpul surya tersebut. Karena bagian sisi relatif kecil dibandingkan dengan bagian dasar dan atas maka kehilangan panas melalui bagian sisi ini diabaikan.

Pengumpul surya yang baik ditentukan oleh reka bentuk (design) dan bahan yang digunakan untuk membuat pengumpul surya tersebut. Secara garis besar pengumpul surya terdiri dari penutup, plat penyerap dan kotak berisolasi. Salah satu bagian terpenting dari pengumpul surya ialah bagian penyerap. Beberapa jenis pengumpul surya yang telah diteliti adalah pengumpul surya tanpa penutup, pengumpul surya satu penutup dan pengumpul surya dua penutup [2]. Pengumpul surya tanpa penutup hanya sesuai untuk digunakan di daerah yang mempunyai suhu rendah dan kenaikan suhu udara yang dihasilkan hanya sekitar $10^{\circ} \mathrm{C}[1]$.

Atas dasar saluran udaranya terdapat pengumpul surya saluran depan, pengumpul surya saluran belakang, pengumpul surya saluran sejajar, pengumpul surya dua-pass [1]. Untuk memperbanyak panas yang dapat diserap, dirancang 
pengumpul surya plat gelombang [13], yang kemudian dikaji lebih lanjut dengan plat penyerap lekuk-V dan pengumpul surya dengan plat penyerap berfin $[3,4]$ dan pengumpul surya dengan media berpori dua penutup [8]. Kemudian pengumpul surya plat datar dua-pass, satu penutup dengan media berpori pada saluran bawah dirancang dan diteliti oleh Supranto [12], dan pengumpul surya dengan penyerap matrik [5].

Skema dari pengumpul surya dua-pass dengan media berpori seperti gambar 1 sebagai berikut:

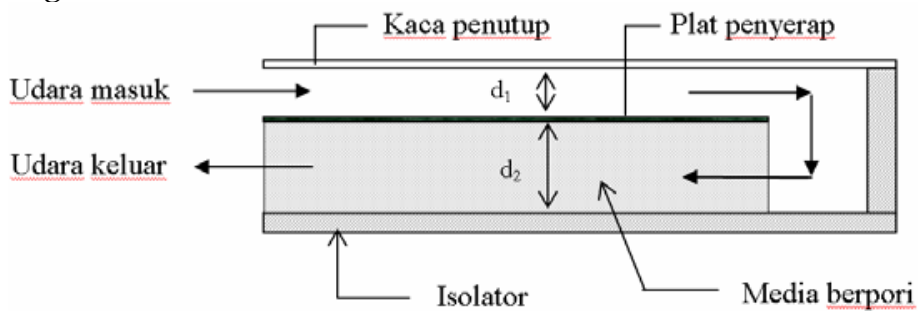

Gambar 1. Skema pengumpul surya dua-pass dengan media berpori

Pada keadaan mantap terjadi perpindahan panas sebagai berikut:

a. Pada kaca penutup:

$$
\alpha S=h_{a}\left(T_{g}-T_{a}\right)+h_{r p g}\left(T_{g}-T_{p}\right)+h_{c f 1 g}\left(T_{g}-T_{f 1}\right)
$$

b. Pada udara dalam saluran atas:

$$
\frac{m \dot{C}_{P}}{d_{1}} \frac{d T_{f 1}}{d x}=h_{c f 1 g}\left(T_{g}-T_{f 1}\right)+h_{c p f 1}\left(T_{p}-T_{f 1}\right)
$$

c. Pada udara dalam saluran bawah:

$$
-\frac{m \dot{C}_{P}}{d_{2}} \frac{d T_{f 2}}{d x}=k_{\text {eff }} \frac{d^{2} T_{f 2}}{d x^{2}}+h_{c p f 2}\left(T_{p}-T_{f 2}\right)+U\left(T_{a}-T_{f 2}\right)
$$

Pada plat penyerap terjadi perpindahan panas ke media berpori dan ke udara. Selanjutnya dari media berpori terjadi perpindahan panas secara konveksi ke udara dalam saluran bawah ini. Selain itu perpindahan panas secara konveksi juga terjadi dari plat penyerap ke udara dalam saluran atas. Selain perpindahan panas secara konduksi, juga terjadi perpindahan panas secara radiasi dari plat penyerap ke media berpori dan dari plat penyerap ke udara dalam salurn atas dan ke udara dalam saluran bawah. Sehingga neraca panas dalam keadaan mantap yang terjadi pada plat penyerap adalah:

$$
\tau_{g} S \alpha_{p}-h_{r p p r}\left(T_{p}-T_{p r}\right)-h_{r p g}\left(T_{p}-T_{g}\right)-h_{c p f 1}\left(T_{p}-T_{f 1}\right)-h_{c p r f 2}\left(T_{p}-T_{f 2}\right)=0
$$

Selanjutnya efisiensi dari pengumpul surya didefinisikan sebagai perbandingan antara panas yang digunakan untuk menghasilkan udara panas dengan sinar surya yang menimpa pengumpul surya. Hal tersebut dapat dinyatakan seperti persamaan (5). 


$$
\eta_{t h}=\frac{m C_{f}\left(T_{o}-T_{i}\right)}{A_{c} S}
$$

Seperti dibicarakan di muka, bahwa tidak semua energi yang diterima oleh pengumpul surya dapat digunakan untuk memanaskan udara yang mengalir di dalam pengumpul surya. Hal ini menyebabkan adanya efisiensi pengumpul surya. Perpindahan panas dalam pengumpul surya dan dari pengumpul surya ke sekeliling dapat terjadi secara konveksi radiasi dan konduksi.

Koefisien perpindahan panas secara konveksi yang terjadi dapat diperkirakan dari bilangan Nusselt sebagai fungsi dari bilangan Reynold dan bilangan Prandtl (Nasr, et al., 1995), seperti dalam persamaan (6) sabagai berikut:

$$
N u=0.0333 \operatorname{Re}^{0.8} \operatorname{Pr}^{\frac{1}{3}}
$$

Sedangkan koefisien perpindahan panas secara radiasi dapat diperkirakan dengan persamaan (7).

$$
h_{r}=\frac{\sigma\left(T_{1}^{2}+T_{2}^{2}\right)\left(T_{1}+T_{2}\right)}{\left(\frac{1}{\varepsilon_{1}}+\frac{1}{\varepsilon_{2}}-1\right)}
$$

Efisiensi termal pengumpul surya dapat diperhitungkan secara teoritis dengan memperkirakan panas yang hilang ke sekeliling. Dengan demikian panas yang dapat dimanfaatkan untuk menghasilkan udara panas dapat diperkirakan, sedangkan efisiensi sebenarnya dapat dihitung dari hasil penelitan berdasarkan data-data suhu udara masuk dan suhu udara keluar pengumpul, debit udara dan intensitas, yang diukur dari hasil penelitian.

\section{BAHAN DAN PELAKSANAAN PENELITIAN}

Penelitian dilakukan di dalam laboratorium terhadap pengumpul surya dua-pass dengan media berpori. Pengumpul surya dua-pass dengan kaca penutup. Pengumpul surya mempunyai ukuran panjang $240 \mathrm{~cm}$, lebar $120 \mathrm{~cm}$, tinggi saluran atas dan tinggi saluran bawah dapat diubah-ubah. Media berpori diletakkan pada saluran bawah sesuai dengan tinggi celah saluran bawah. Sebagai kaca penutup digunakan kaca jendela berbintik-bintik tebal 0,5 cm, yang dipasang dengan bagian bintik menghadap ke dalam, hal ini dimaksudkan agar kehilangan panas melalui kaca penutup dapat diminimalkan. Untuk plat penyerapnya digunakan plat aluminium $0,8 \mathrm{~mm}$ dan dicat hitam tidak mengkilat. Sebagai sumber energi surya digunakan simulator surya. Simulator surya terdiri dari 45 lampu halogen dichroic, $300 \mathrm{~W}$. Masing-masing lampu dilengkapi dengan regulator, sehingga intensitas lampu dapat diubah-ubah sesuai dengan intensitas yang dikehendaki. Simulator surya mempunyai luas bidang penyinaran $\pm 6 \mathrm{~m}^{2}$. Pengumpul surya diletakkan $160 \mathrm{~cm}$ di bawah simulator surya. Simulator surya dapat menghasilkan intensitas sinaran rata-rata $\pm 640 \mathrm{~W} / \mathrm{m}^{2}$. Skema rangkaian alat untuk penelitian seperti gambar 2 . 

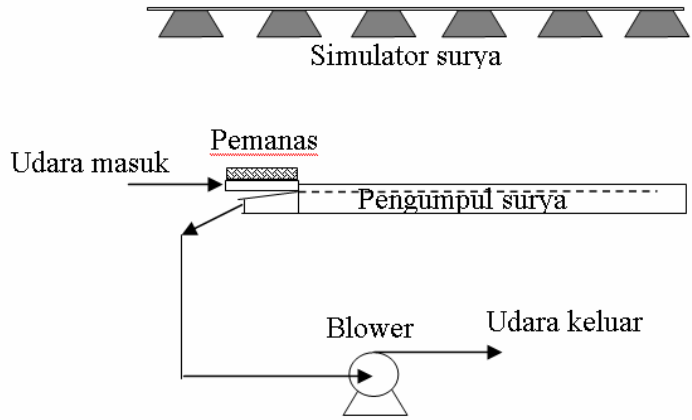

Gambar 2. Rangkaian alat penelitian

Mula-mula dilakukan penelitian untuk mendapatkan kontur intensitas pada permukaan pngumpul surya. Dari data kontur intensitas ini akan dapat dihitung intensitas rata-rata untuk setiap tenaga listrik yang dibekalkan. Setelah didapatkan intensitas rata-rata, kemudian percobaan diteruskan dengan variasi debit udara dan intensitas. Mula-mula simulator surya dinyalakan, kemudian blower dihidupkan. Dari percobaan ini akan diperoleh data suhu udara masuk dan keluar pengumpul surya, intensitas pada permukaan pengumpul surya dan debit udara yang mengalir dalam pengumpul surya. Setelah diperoleh suhu udara yang stabil maka penelitian dilanjutkan dengan memvariasi debit udara pada setiap intensitas. Salah satu faktor yang berpengaruh terhadap efisiensi pengumpul surya adalah tipe aliran udara. Aliran turbulen akan menyebabkan perpindahan panas antara plat penyerap dengan udara yang lebih baik (Matrawy \& Farkas, 1994), sedangkan penelitian Parker, et al. (1984) dan Pratoto, et al.(1997), tinggi celah saluran udara besar pengaruhnya terhadap turbulensi aliran udara dalam pengumpul surya, maka penelitian dilanjutkan dengan mengubah-ubah tinggi celah aliran udara. Celah aliran udara pertama diubah $3,5 \mathrm{~cm}$ dan $7,0 \mathrm{~cm}$, sedangkan tinggi celah aliran udara kedua diubah-ubah $7,0 \mathrm{~cm}, 10,5 \mathrm{~cm}$ dan 14,0 $\mathrm{cm}$. Selanjutnya percobaan dilakukan pada setiap debit udara dan intensitas.

\section{HASIL PENELITIAN DAN PEMBAHASAN}

Penelitian pengumpul surya merupakan penelitian yang sangat tergantung pada alam, sehingga untuk penelitian efisiensi ini penelitian dilaksanakan di dalam laboratorium, dengan penelitian dalam laboratorium dapat dilakukan pengendalian intensitas sinar. Hal ini dapat dilakukan karena sebagai sumber cahaya digunakan simulator surya dengan tenaga lampu listrik. Intensitas tergantung pada tenaga listrik yang dibekalkan. Selain itu tegangan yang masuk juga dapat diatur sesuai dengan rencana penelitian yang stabil selama penelitian. Selain itu selama penelitian diambil beberapa asumsi, diantaranya adalah; kelembapan udara dianggap tetap, kecepatan angin dianggap tetap, debu di dalam ruangan dianggap tetap dan tegangan listrik selama penelitian juga dianggap tetap. 
Sebelum dilakukan penelitian yang sebenarnya dilakukan dulu pengujian simulator surya. Hal ini dilakukan untuk membuat intensitas penyinaran yang merata. Meskipun sebenarnya untuk menghasilkan intensitas yang benar-benar merata sangat sukar. Salah satu contoh hasil pengujian simulator surya seperti gambar 3 berikut.
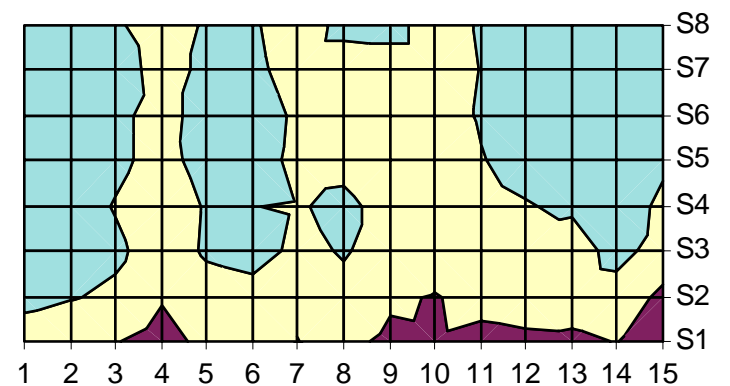

$\square$ 400-450 $\square 450-500 \quad \square 500-550 \quad \square 550-600$

Gambar 3. Kontur hasil simulator surya dengan intensitas rata-rata $530,5 \mathrm{~W} / \mathrm{m}^{2}$

Setelah didapatkan kontur simulator surya, kemudian dilakukan percobaan yang sebenarnya. Perbandingan antara hasil perhitungan dan hasil percobaan yang dilakukan terhadap pengumpul surya dengan variasi tinggi celah saluran udara, intensitas dan debit udara akan diperoleh gambar 3, gambar 4 dan gambar 5 , yang merupakan hubungan antara debit udara dengan suhu udara keluar. Kemudian hubungan antara debit udara dengan efisiensi seperti gambar 4. gambar 5 dan gambar 6 . Sedangkan hubungan antara debit dengan efisiensi seperti digambarkan pada gambar 7, gambar 8, dan gambar 9 berikut :

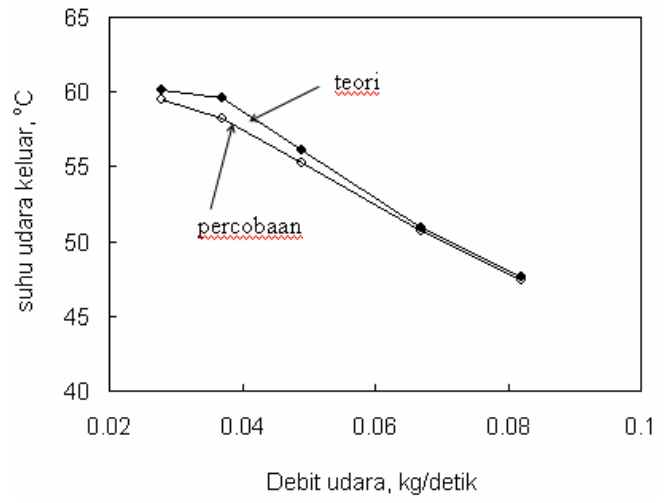

Gambar 4. Hubungan antara debit udara dengan suhu udara keluar, tinggi saluran atas $3,5 \mathrm{~cm}$ dan saluran bawah 7 $\mathrm{cm}$ pada intensitas $553,5 \mathrm{~W} / \mathrm{m}^{2}$



Gambar 5. Hubungan antara debit udara dengan suhu udara keluar, tinggi saluran atas $3,5 \mathrm{~cm}$ dan saluran bawah $7 \mathrm{~cm}$ pada intensitas 530,5 W/ $\mathrm{m}^{2}$ 


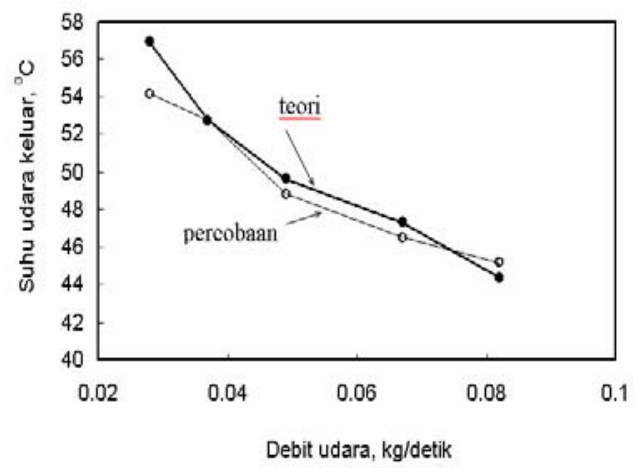

Gambar 6. Hubungan antara debit udara dengan suhu udara keluar, tinggi saluran atas $3,5 \mathrm{~cm}$ dan saluran bawah 7 $\mathrm{cm}$ pada intensitas $482,2 \mathrm{~W} / \mathrm{m}^{2}$

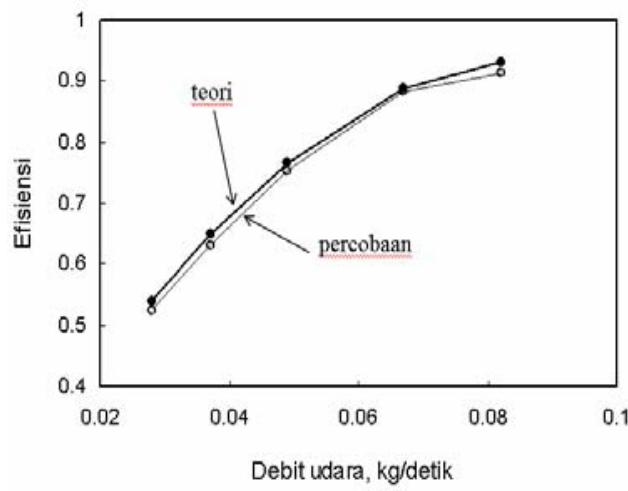

Gambar 8. Hubungan antara debit udara denganefisiensi, tinggi saluran atas 3,5 $\mathrm{cm}$ dan saluran bawah $7 \mathrm{~cm}$ pada intensitas 530,5 W/m²

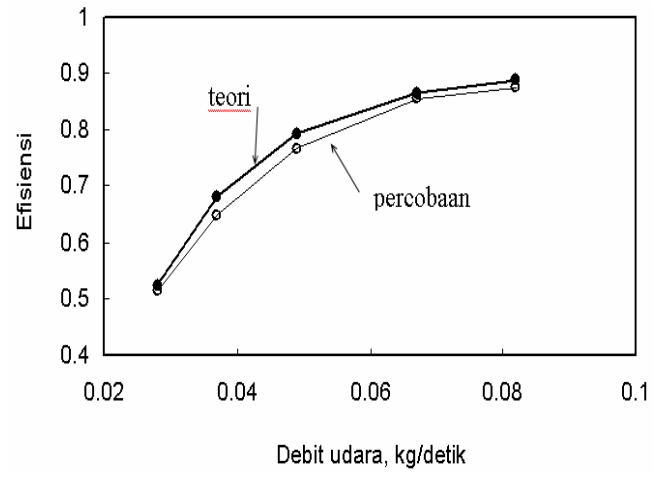

Gambar 7. Hubungan antara debit udara dengan efisiensi, tinggi saluran atas 3,5 $\mathrm{cm}$ dan saluran bawah $7 \mathrm{~cm}$ pada intensitas 553,5 W/m²

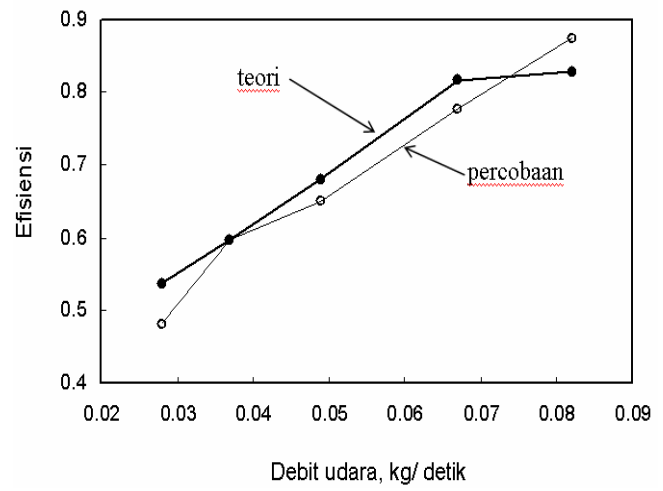

Gambar 9. Hubungan antara debit udara dengan efisiensi, tinggi saluran atas 3,5 $\mathrm{cm}$ dan saluran bawah $7 \mathrm{~cm}$ pada intensitas $482,2 \mathrm{~W} / \mathrm{m}^{2}$

\section{SIMPULAN}

Dari percobaan yang dilakukan ternyata diperoleh data yang tidak jauh berbeda dengan kajian teori. Pada umumnya data percobaan lebih rendah daripada kajian teori. Perbedaan ini terjadi, karena untuk kajian teori beberapa konstanta dianggap tetap. Misalnya koefisien perpindahan panas, yang meliputi konstanta perpindahan panas secara konduksi, konveksi maupun radiasi. Dalam kajian teori semua konstanta perpindahan panas tersebut dianggap tetap, padahal sebenarnya konstanta perpindahan panas dipengaruhi oleh suhu. Demikian pula sifat-safat udara juga dianggap tetap, padahal sebenarnya terjadi perubahan dari sifat-sifat udara. Berat jenis udara merupakan besaran yang sangat dipengaruhi oleh suhu, pada suhu yang tinggi berat jenis udara lebih kecil daripada berat jenisnya pada suhu yang lebih rendah. Demikian pula untuk viskositas udara, juga dipengaruhi oleh suhu. Selain berpengaruh terhadap sifat-sifat udara, kenaikan suhu juga berpengaruh terhadap profil aliran udara. Kenaikan suhu udara sampai 
keadaan tertentu dapat menyebabkan terjadinya turbulensi aliran udara. Turbulensi aliran selain disebabkan oleh kecepatan linier dan adanya penghalang (isian), juga disebabkan kenaikan suhu ini. Dengan adanya turbulensi aliran udara akan menyebabkan perpindahan panas dari plat penyerap ke udara menjadi lebih baik, sehingga panas yang dapat dipindahkan dari plat penyerap ke udara lebih besar. Turbulensi aliran udara akan menyebabkan kontak yang lebih baik dengan kaca penutup, hal ini akan menyebabkan suhu kaca penutup menjadi lebih tinggi, akibatnya kehilangan panas melalui kaca penutup menjadi lebih besar. Jadi banyak faktor yang berpengaruh terhadap perpindahan panas dari plat penyerap ke udara dalam pengumpul surya, demikian pula sangat kompleks kehilangan panas ke udara di sekitar pengumpul surya. Sehingga untuk analisis perlu diadakan asumsi-asumsi, diantaranya dengan menganggap tetap untuk sifat-sifat udara dan beberapa konstanta.

\section{PUSTAKA}

[1] Brenndorfer, B., Kennedy, L., Bateman, C.O.O, Trim, D.S., Mrema, G.C. \& Werekobrobby, C. (1985) Solar dryers-their role in post-harvest processing. London: Commonwealth Science Council: 48-59

[2] Edwards, D.K. (1977) Solar absorption by each element in an absorber coverglass array. Solar Energy. 19: 401-402

[3] Garg, H. P. (1991) Advances in solar energy technology, vol. 3, Heating, Agricultural and photovoltaic applications of solar energy. Dordrecht: D. Reidel Publishing Company: 120-122, 153-155

[4] Hachemi, A. (1999) Experimental study of thermal performance of offset rectangular plate fin absorber plates. Renewable Energy. 17: 371-384

[5] Kolb, A.E., Winter, R.F. \& Vislanta, R. (1999) Experimental studies on a solar air collector with matrix absorber, Solar Energy, 65, 2, 91-99

[6] Maskurun. (1986) Peranan Profesi Teknik Kimia di dalam Meningkatkan Konservasi Energi Industri, Seminar Teknik Kimia 1986, Jurusan Teknik Kimia, Fakultas Teknik, Undip

[7] Matrawy, K.K. \& Farkas, I. (1994) Comparison between two configurations of flat-plate collectors, Renewable Energy Volume 5, Part III, 1928-1930

[8] Mohamad, A.A. (1997) High efficiency solar air heater, Solar Energy, 60, 2, 71-76

[9] Nasr K.J., Ramadhyani S. and Viskanta R. (1995) Numerical studies of forced convection heat transfer from a cylinder embedded in a packed bed, Int. J. Heat and Mass Trans. 38, 2353 - 2366

[10] Parker, B.F., Colliver, D.E. \& Walton, L.R. (1984) Sensitivity of air-type solar collector efficiency to design changes, Trans. ASAE, 27, 915-920

[11] Pratoto, A., Daguenet, M. \& Zeghmati, B. (1997) Sizing solar assisted natural rubber dryers, Solar Energy, 61, 4, 281-287

[12] Supranto. (2000) Reka Bentuk dan Penilaian Sistem Pengering Terbantu Suria Dua Laluan dengan Media Berliang, Disertasi Doktor Falsafah, Universiti Kebangsaan Malaysia, Kuala Lumpur.

[13] William J.R. (1988). Design and installation of Solar heating and hot water system, Ann Arbor Science, The Butterworth Group, London, pp. 85-88 